\title{
Purification and properties of an alanine aminopeptidase from camel liver
}

\author{
Hassan Mohamed Masoud", Doaa Abdel-Khalek Darwish, Mohamed Salah-Eldin Helmy, \\ Mohamed Mosaad Abdel-Monsef \\ Molecular Biology Department, National Research Centre, Dokki, Giza, Egypt.
}

\begin{tabular}{|c|c|}
\hline ARTICLE INFO & ABSTRACT \\
\hline Article history: & \multirow{8}{*}{$\begin{array}{l}\text { Alanine aminopeptidase is purified from camel liver to homogeneity and designated CLAAP. The purification } \\
\text { procedure involved anion exchange chromatography on DEAE-cellulose column and gel filtration } \\
\text { chromatography on Sephacryl S-300 column. The specific activity of CLAAP is increased to } 9.9 \text { folds over the } \\
\text { crude extract with } 25.3 \% \text { yields. The purified CLAAP is homotrimmer protein with } 180 \mathrm{kDa} \text { consists of three } \\
\text { identical subunits of } 60 \mathrm{kDa} \text { each. CLAAP displayed its optimum activity at } \mathrm{pH} 8.0 \text { and the Km value is } 0.083 \\
\mathrm{mM} \text { alanine } \beta \text {-naphthylamide. The divalent cations } \mathrm{CuCl}_{2}, \mathrm{MnCl}_{2} \text { and } \mathrm{ZnCl}_{2} \text { inhibited CLAAP activity while } \\
\mathrm{CoCl}_{2} \text { and } \mathrm{MgCl}_{2} \text { increased its activity. CLAAP was inhibited competitively with bestatin that has one binding } \\
\text { site on the enzyme and } \mathrm{Ki} \text { value of } 14 \mu \mathrm{M} \text {. This report represents AAP purified from the camel liver as a safe } \\
\text { source. Therefore, a task for the future will be the application of this purified CLAAP enzyme in the industry of } \\
\text { meat and dairy products for flavor development. }\end{array}$} \\
\hline Received on: $03 / 10 / 2016$ & \\
\hline Accepted on: $20 / 01 / 2017$ & \\
\hline Available online: $30 / 05 / 2017$ & \\
\hline Key words: & \\
\hline Alanine aminopeptidase; & \\
\hline Camel liver; Purification; & \\
\hline Characterization. & \\
\hline
\end{tabular}

\section{INTRODUCTION}

Aminopeptidases are exopeptidases proteins that remove the N-terminal amino acid of their protein substrates (Niven, 1995; Erbeznik and Hersh, 1997). These enzymes are widespread in prokaryotes, mammals and plants and their substrate specificities depending on their physiological roles (Barrett et al., 1998; Umetsu et al., 2003; Matsui et al., 2006; Bogra et al., 2009; Mane et al., 2010; Renwrantz and Lam, 2010). These proteins have substantial tasks in numerous physiological processes as it regulates certain pathways in metabolism, controls the cell cycle and selectively degrades certain proteins (Brownless and Williams, 1993). They can be classified into two main types, one hydrolyzes the amino acids with hydrophobic side chains from $\mathrm{N}$-terminus of the protein, and the other removes other amino acid residues (Drag et al., 2005). Alanine aminopeptidases are present in almost all

\footnotetext{
* Corresponding Author

Hassan Mohamed M. Masoud, Molecular Biology Department, National Research Centre, El-Tahrir st., Dokki, Giza, Egypt. Email: hssnasoud @yahoo.com
}

mammalian tissues including intestine, kidney, liver and pancreas (Mane et al., 2010). They are present in many human organs including; seminal plasma (Huang et al., 1997), liver (Yamamoto et al., 2000), placenta (Mizutani et al., 1993), pancreas (Sidorowicz et al., 1980), kidney (Mantle et al., 1990), gallbladder bile (Offner et al., 1994) and skeletal muscle (Mantle et al., 1983). They are present in other mammalian tissues as bovine skeletal muscle (Ye and $\mathrm{Ng}, 2011$ ) and porcine kidney (Itoh and Nagamatsu, 1995). Mammalian aminopeptidases take part in metabolism of neurotransmitters and hormones (Hiroi et al., 1992; Umetsu et al., 2003), used as kidneys damage biomarker and used in diagnosis of certain kidney troubles as they are present at elevated urine percentages if there are kidney disorders (Flynn, 1990). For meat and dairy products industry, aminopeptidases share the flavor development as a direct action by removing bitter peptides which have high ratio of hydrophobic amino acids that are considered as perfect substrates for its action, or indirectly, where aminopeptidases may remove the aromatic amino acids that are main substrates of aromatic molecules present in cheese (Fernandez-Espla and Rul, 1999; Magboul and McSweeney, 1999; Martinez-Cuesta et al., 2001; Ye and Ng, 2011). 
This report represents purification and characterization of alanine aminopeptidase from camel liver as a safe source for the various industrial applications of aminopeptidases.

\section{MATERIALS AND METHODS}

\section{Liver tissues}

Six fresh camel liver samples were obtained from different individuals in a local slaughter-house and stored at -40 ${ }^{\circ} \mathrm{C}$.

\section{Chemicals}

L-Alanine $\beta$-naphthylamide, Dithiothreitol (DTT), Fast Garnet GBC salt, $p$-Hydroxymercuribenzoic acid (pHMBA), 1,10 Phenanthroline, Bovine serum albumin (BSA), Diethylaminoethyl cellulose (DEAE-Cellulose) and Sephacryl S-300 were purchased from Sigma-Aldrich Chemicals Co. The other chemicals were of analytical grade.

\section{Assay of alanine aminopeptidase activity}

The alanine aminopeptidase activity assay reaction mixture contained in $1.5 \mathrm{ml}$ of $0.1 \mathrm{M}$ Tris- $\mathrm{HCl}$ buffer $\mathrm{pH} \mathrm{8,} 0.4$ $\mathrm{mM}$ alanine- $\beta$-naphthylamide and the enzyme solution. Incubate for 1 hour at $37^{\circ} \mathrm{C}$; stop the reaction with $0.5 \mathrm{ml}$ Fast Garnet GBC solution $(1 \mathrm{mg} / \mathrm{ml})$ in $1 \mathrm{M}$ acetate buffer $\mathrm{pH} 4.2$ containing $10 \%$ Tween 20 and read absorbance at $525 \mathrm{~nm}$ against control lacking enzyme. The concentration of the liberated $\beta$-naphthylamine was calculated from a standard curve of $\beta$-naphthylamine treated similarly. One unit of alanine aminopeptidase activity is the amount of enzyme which catalyzes the liberation of $1 \mathrm{nmol}$ of $\beta$ naphthylamine per hour at $37^{\circ} \mathrm{C}$ (Kawata et al., 1980).

\section{Staining of alanine aminopeptidase activity on PAGE}

After electrophoresis, the gel was incubated in $50 \mathrm{ml} 0.1$ $\mathrm{M}$ sodium phosphate buffer $\mathrm{pH} 5.8$ containing $1 \mathrm{mM} \mathrm{CoCl}_{2}$, $0.06 \%$ alanine $\beta$-naphthylamide $\mathrm{HCl}$ and $0.06 \%$ Fast Garnet GBC salt until the develop of the red bands. The stained gel was washed with water and then fixed in $7 \%$ acetic acid (Chien et al., 2002).

\section{Purification of camel liver alanine aminopeptidase Preparation of crude extract}

All of the procedures were performed at $4{ }^{\circ} \mathrm{C}$ unless stated otherwise. 10 grams of camel liver were homogenized in $0.02 \mathrm{M}$ sodium phosphate buffer $\mathrm{pH} 7.4$ using Omni mixer homogenizer. Cell debris and insoluble materials were removed by centrifugation at $5000 \times \mathrm{g}$ for $20 \mathrm{~min}$ and the supernatant was saved and designated as crude extract.

\section{DEAE-cellulose column Chromatography}

The crude extract was chromatographed on DEAEcellulose column previously equilibrated with $0.02 \mathrm{M}$ sodium Phosphate buffer $\mathrm{pH}$ 7.4. The proteins were eluted with stepwise $\mathrm{NaCl}$ gradient ranging from 0 to $1 \mathrm{M}$ followed by $0.5 \%$ Triton $\mathrm{X}$ -
100 prepared in the equilibration buffer. Fractions of $5 \mathrm{ml}$ were collected at a flow rate of $60 \mathrm{ml} /$ hour. Fractions containing alanine aminopeptidase activity were pooled and concentrated by lyophilization.

\section{Sephacryl S-300 column Chromatography:}

The concentrated solution containing the alanine aminopeptidase activity was applied onto a Sephacryl S-300 column (142 cm x $1.75 \mathrm{~cm}$ i.d.). The column was equilibrated and developed with $0.02 \mathrm{M}$ sodium Phosphate buffer $\mathrm{pH} 7.4$ at a flow rate of $30 \mathrm{ml}$ / hour and $2 \mathrm{ml}$ fractions were collected.

\section{Electrophoretic analysis}

Native gel electrophoresis was carried out with $7 \%$ PAGE (Smith, 1969). The subunit molecular weight of the purified enzyme was determined by $12 \%$ SDS-PAGE (Weber and Osborn, 1969; Laemmli, 1970). Coomassie brilliant blue R-250 was used to stain the proteins.

\section{Protein determination}

Protein content was determined by the dye binding assay method using BSA as a standard protein (Bradford, 1976).

\section{RESULTS}

\section{Purification of camel liver alanine aminopeptidase}

The purification of the major AAP from camel liver crude extract was monitored by ability of AAP to hydrolyze the substrate alanine- $\beta$-naphthylamide and the results of the purification is outlined in Table (1).

Table 1: Purification scheme of camel liver alanine aminopeptidase (CLAAP).

\begin{tabular}{lllllll}
\hline \multicolumn{1}{c}{ Purification step } & 228 & 99400 & 436.0 & 100.0 & 1.0 \\
& 26.7 & 55736 & 2087.5 & 56.1 & 4.9 \\
\hline $\begin{array}{l}\text { Camel liver crude extract } \\
\begin{array}{l}\text { (0.5\% \% Triton) } \\
\text { Sephacryl S-300 fraction }\end{array}\end{array}$ & 5.8 & 25120 & 4331.0 & 25.3 & 9.9 \\
\hline
\end{tabular}

The camel liver crude extract AAP specific activity was measured as 436 units/mg protein. Alanine aminopeptidase was purified with two chromatographic steps on DEAE-cellulose and Sephacryl S-300 columns. The elution profile of AAP on the anion exchange column showed one principal AAP activity peak (Fig. 1a) collected from the column with $0.5 \%$ Triton $X-100$ and designated as CLAAP and a minor AAP activity peak eluted with $0.2 \mathrm{M} \mathrm{NaCl}$. The CLAAP peak was collected, lyophilized and further purified by a gel filtration Sephacryl S-300 column (Fig. 1b). After gel filtration chromatography, the CLAAP was purified with 4331 units/mg specific activity representing 9.9 folds and $25.3 \%$ yield. The CLAAP enzyme eluted from Sephacryl S-300 column with a native molecular mass of $180 \mathrm{kDa}$. 

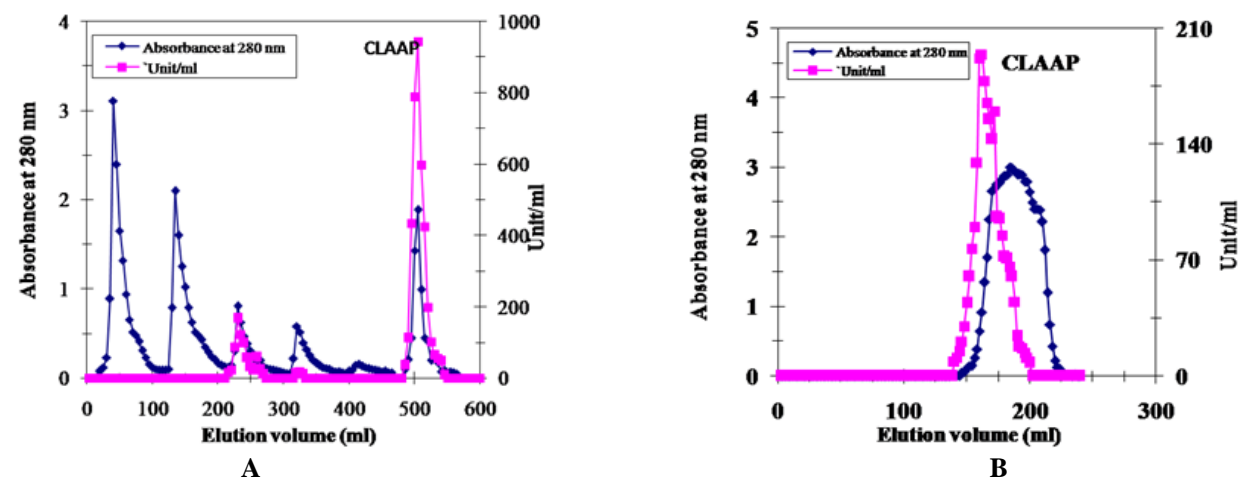

Fig. 1: (a) A typical elution profile for the chromatography of camel liver crude extract on DEAE-cellulose column $(6 \mathrm{~cm} \times 2.4 \mathrm{~cm}$ i.d.) previously equilibrated with $0.02 \mathrm{M}$ sodium Phosphate buffer $\mathrm{pH}$ 7.4. The proteins were eluted by a stepwise gradient of $\mathrm{NaCl}$ ranging from 0 to $1 \mathrm{M}$ followed by $0.5 \%$ Triton $\mathrm{X} 100$ in the equilibration buffer. $5 \mathrm{ml}$ fractions were collected at a flow rate of $60 \mathrm{ml} / \mathrm{h}$. (b) A typical elution profile for the chromatography of CLAAP on Sephacryl S300 column $(142 \mathrm{~cm}$ x $2.4 \mathrm{~cm}$ i.d.) previously equilibrated with $0.02 \mathrm{M}$ sodium Phosphate buffer $\mathrm{pH}$ 7.4. The proteins were eluted by the same buffer and $2 \mathrm{ml}$ fractions were collected at a flow rate of $30 \mathrm{ml} / \mathrm{h}$

\section{Analyses of CLAAP on polyacrylamide gel electrophoresis}

The CLAAP enzyme purification cycles including liver extract, anion exchange fraction and gel filtration fraction were seen on $7 \%$ native PAGE (Fig. 2a). The purified enzyme was seen as a single protein band corresponded with the enzyme activity band (Fig. 2b) demonstrating the tentative purity of the preparation. CLAAP enzyme was seen on SDS-PAGE as a single band of $60 \mathrm{kDa}$ (Fig. 2c) which indicates the subunit molecular weight of the purified enzyme.
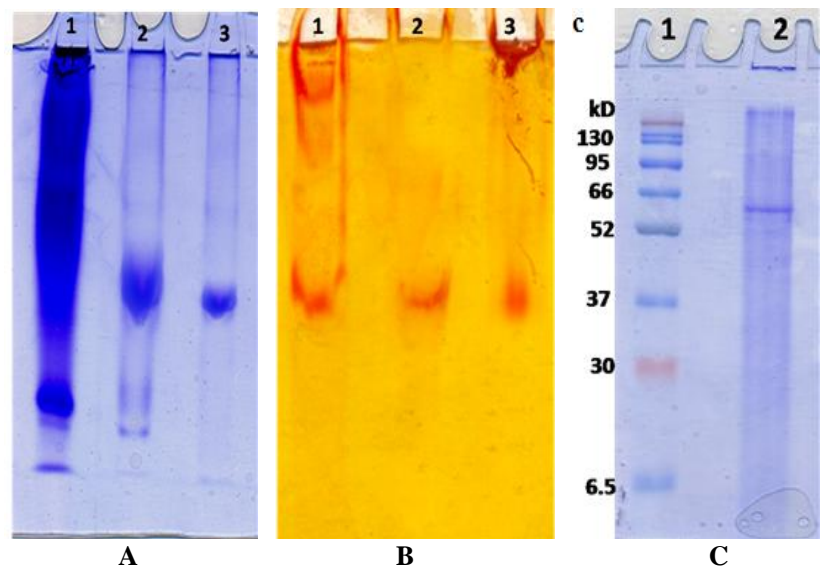

Fig. 2: (a) Electrophoretic analysis of protein pattern of CLAAP on $7 \%$ native PAGE: (1) crude extract, (2) DEAE-cellulose fraction, (3) Sephacryl S-300 purified fraction. (b) Electrophoretic analysis of alanine aminopeptidase isoenzyme pattern of CLAAP on $7 \%$ native PAGE: (1) crude extract, (2) DEAE-cellulose fraction, (3) Sephacryl S-300 purified fraction (c) Molecular weight determination of CLAAP subunit by $12 \%$ SDS-PAGE: (1) Molecular weight marker proteins and (2) Purified CLAAP.

\section{Substrate specificity, Optimum $\mathrm{pH}$ and $\mathrm{Km}$ value determination of CLAAP}

The substrate specificity of the purified camel liver alanine aminopeptidase (CLAAP) was screened toward various substrates (Table 2). CLAAP cleaved preferentially alanine$\beta$-naphthylamide HCI (100\% relative activity) followed by leucine- $\beta$-naphthylamide $(87.8 \%)$ and displayed low activity toward glycine- $\beta$-naphthylamide (61.9\%). The optimum $\mathrm{pH}$ of the purified CLAAP enzyme was tested with potassium phosphate buffer, $\mathrm{pH}(7.0-9.0)$. The $\mathrm{pH}$ profile of CLAAP displayed its optimum activity at $\mathrm{pH} 8.0$ (Fig. 3a).

The Lineweaver-Burk plot calculates the Km value of the purified enzyme from $(1 / \mathrm{v})$ and $(1 /[\mathrm{S}])$ to be $0.083 \mathrm{mM}$ alanine $\beta$ naphthylamide (Fig. 3b).

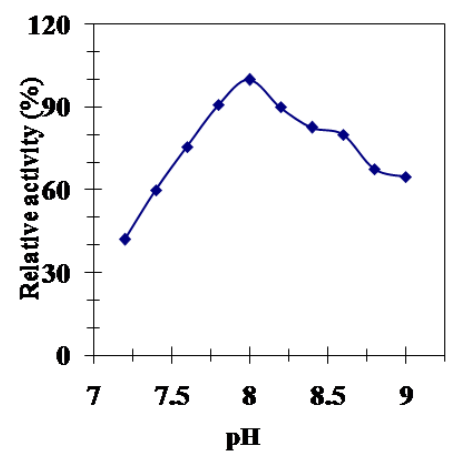

A

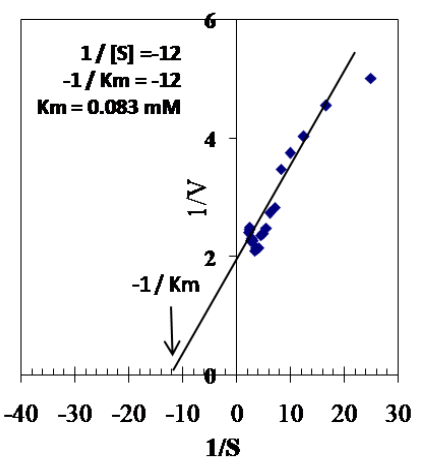

B
Fig. 3: (a) Effect of $\mathrm{pH}$ on the purified CLAAP using $0.05 \mathrm{M}$ potassium phosphate buffer, $\mathrm{pH}(7.0-9.0)$. (b) Lineweaver-Burk plot relating the reciprocal of the reaction velocity of the purified CLAAP to alanine $\beta$ naphthylamide concentration in $\mathrm{mM}$.

Table 2: Substrate specificity of camel liver alanine aminopeptidase (CLAAP):

\begin{tabular}{|c|c|c|c|}
\hline \multirow[b]{2}{*}{ Substrate } & \multirow[b]{2}{*}{ 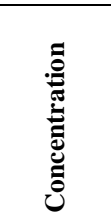 } & \multicolumn{2}{|c|}{ CLAAP } \\
\hline & & 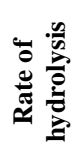 & 糈 \\
\hline DL-Alanine- $\beta$-naphthylamide HCI & $0.4 \mathrm{mM}$ & 0.352 & 100.0 \\
\hline Glycine- $\beta$-naphthylamide $\mathrm{HCI}$ & $0.4 \mathrm{mM}$ & 0.218 & 61.9 \\
\hline L-Leucine- $\beta$-naphthylamide HCI & $0.4 \mathrm{mM}$ & 0.309 & 87.8 \\
\hline
\end{tabular}

The hydrolysis rate is the change in absorbance at $525 \mathrm{~nm}$ for $\beta$ - naphthylamide derivatives per $30 \mathrm{~min}$. 


\section{Effect of divalent cations and various inhibitors on CLAAP activity}

The purified camel liver alanine aminopeptidase CLAAP was pre-coupled with two different concentrations of all divalent cations at $37^{\circ} \mathrm{C}$ then test the enzyme activity. These measures were compared with a control test that has no cations. $\mathrm{CuCl}_{2}, \mathrm{MnCl}_{2}$ and $\mathrm{ZnCl}_{2}$ inhibited the activity of CLAAP while $\mathrm{CoCl}_{2}$ and $\mathrm{MgCl}_{2}$ were found to be activators of the enzyme activity (Table 3). Furthermore, we preincubated the CLAAP with different inhibitors for $5 \mathrm{~min}$ at $37^{\circ} \mathrm{C}$ then calculated the percent of inhibition in comparison with control with no inhibitors. Bestatin was the potent CLAAP enzyme activity inhibitor (Table 4).

Table 3: Effect of divalent cations on the purified camel liver alanine aminopeptidase CLAAP.

\begin{tabular}{ccc}
\hline Reagent & Concentration (mM) & Residual Activity (\%) \\
\hline Control & ---- & 100.0 \\
\hline \multirow{2}{*}{$\mathrm{CoCl}_{2}$} & 1.0 & 105.4 \\
& 2.0 & 122.7 \\
\hline \multirow{2}{*}{$\mathrm{MnCl}_{2}$} & 1.0 & 50.7 \\
& 2.0 & 13.6 \\
\hline \multirow{2}{*}{$\mathrm{FeCl}_{2}$} & 1.0 & 94.7 \\
& 2.0 & 82.6 \\
\hline \multirow{2}{*}{$\mathrm{ZnCl}_{2}$} & 1.0 & 76.0 \\
& 2.0 & 54.5 \\
\hline \multirow{2}{*}{$\mathrm{CuCl}_{2}$} & 1.0 & 37.1 \\
& 2.0 & 10.6 \\
\hline \multirow{2}{*}{$\mathrm{NiCl}_{2}$} & 1.0 & 96.2 \\
& 2.0 & 89.1 \\
\hline \multirow{2}{*}{$\mathrm{MgCl}_{2}$} & 1.0 & 98.8 \\
& 2.0 & 115.9 \\
\hline \multirow{2}{*}{$\mathrm{CaCl}_{2}$} & 1.0 & 87.3 \\
\end{tabular}

Table 4: Effect of inhibitors on the purified camel liver alanine aminopeptidase (CLAAP).

\begin{tabular}{lcc}
\hline \multicolumn{1}{c}{ Reagent } & Concentration & $\begin{array}{c}\text { Inhibition } \\
(\%)\end{array}$ \\
\hline \multicolumn{1}{c}{ Control } & ---- & 0.0 \\
Bestatin & $100 \mu \mathrm{M}$ & 97.8 \\
Cysteine & $5 \mathrm{mM}$ & 14.2 \\
DL-Dithiothreitol (DTT) & $5 \mathrm{mM}$ & 4.7 \\
Ethylenediamine tetraacetic acid (EDTA) & $5 \mathrm{mM}$ & 15.3 \\
N-Ethylmalimide & $5 \mathrm{mM}$ & 5.5 \\
p-Hydroxymercuribenzic acid (pHMBA) & $1 \mathrm{mM}$ & 58.0 \\
Glutathione (GSH) & $5 \mathrm{mM}$ & 70.3 \\
Iodoacetic acid & $10 \mathrm{mM}$ & 19.3 \\
$\begin{array}{l}\text { B-Mercaptoethanol } \\
\text { 1,10 Phenanthroline }\end{array}$ & $5 \mathrm{mM}$ & 3.6 \\
Phenylmethylsulfonylfluoride (PMSF) & $10 \mathrm{mM}$ & 80.1 \\
Puromycin & $5 \mathrm{mM}$ & 62.0 \\
N-Tosyl-lysine chloromethyl ketone & $1 \mathrm{mM}$ & 28.6 \\
hydrochloride (TLCK) & $5 \mathrm{mM}$ & 58.7 \\
N-Tosylamide-L-phenylalanine & & \\
chloromethyl ketone (TPCK) & $5 \mathrm{mM}$ & 2.5 \\
* These values represent \% of the control and the means of triplicate \\
experiments.
\end{tabular}

\section{Kinetics of CLAAP inhibition by Bestatin}

The purified enzyme CLAAP activity was inhibited strongly with bestatin. The enzyme was subjected to inhibition with increasing concentrations of bestatin making a titration curve (Fig. 4a) demonstrating that $50 \%$ inhibition $\left(\mathrm{I}_{50}\right)$ of CLAAP activity was reached with $30 \mu \mathrm{M}$ bestatin. Maximum enzyme inhibition of $97.8 \%$ was reached by $100 \mu \mathrm{M}$ bestatin. When the Hill plot for CLAAP inhibition by bestatin was constructed a linear relationship was obtained and the slope of the Hill plot was found 1.11 (Fig. 4b). The CLAAP activity inhibition by bestatin was a competitive type (Fig. 4c) with a $\mathrm{Ki}$ value of $14 \mu \mathrm{M}$ (Fig. $4 d)$.
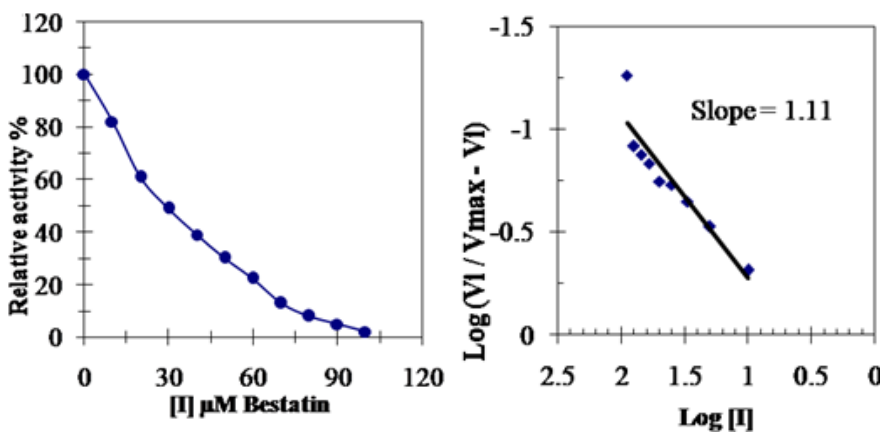

A

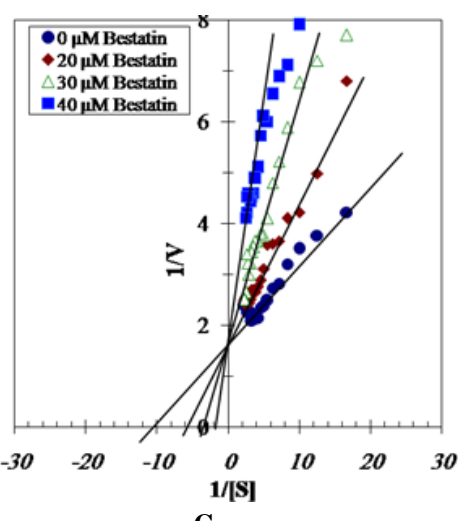

C

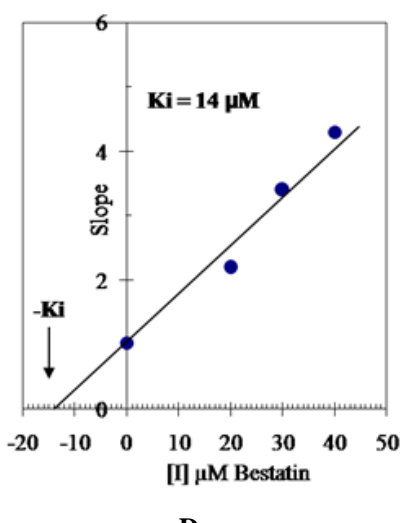

D
Fig. 4: (a) Inhibition of CLAAP by varying concentrations of Bestatin. (b) Hill plot for inhibition of CLAAP by Bestatin. (c) Lineweaver-Burk plots showing the type of inhibition of CLAAP by Bestatin. (d) Determination of the inhibition constant $(\mathrm{Ki})$ value for the inhibition of the CLAAP by Bestatin.

\section{DISCUSSION}

Alanine aminopeptidases are widespread in mammalian tissues and body fluids. They have an important role in liberation of the neutral amino acids of proteins as Alanine, Leucine, Methionine and Tyrosine (Mane et al., 2010). In this study, the camel liver AAP is purified by a simple and reproducible method consists only of two column chromatographic steps which were found to be convenient to set a homogenous form of the enzyme. Separation of the camel liver crude extract on DEAE-cellulose column revealed the existence of one major form of camel liver alanine aminopeptidase termed CLAAP and another minor form (Fig. 1a). CLAAP eluted from the Sephacryl S-300 column as one peak of AAP activity with a native molecular weight of $180 \mathrm{kDa}$ (Fig. 1b) while its subunit molecular weight is estimated at $60 \mathrm{kDa}$ by SDS-PAGE indicating that the enzyme is homotrimmeric protein consists of three identical subunits (Fig. 2c). The molecular mass of CLAAP is similar to that of $180 \mathrm{kDa}$ alanine aminopeptidase of chicken intestine (Mane et al., 2010) and higher 
than that of $160 \mathrm{kDa}$ chicken intestine (Jamadar et al., 2003), 153 $\mathrm{kDa}$ human seminal plasma (Huang et al., 1997) and $60 \mathrm{kDa}$ bovine skeletal muscle (Ye and $\mathrm{Ng}, 2011$ ). The specific activity of the prepared CLAAP isoenzyme is increased to $4331 \mathrm{U} / \mathrm{mg}$ protein with $25.3 \%$ recovery and 9.9 folds purification (Table 1). Very low recovery of $3.43 \%$ was reported for chicken intestine alanine aminopeptidase (Mane et al., 2010). CLAAP homogeneity is proved by native polyacrylamide gel with a single band for the purified protein which coincided with the band of enzyme activity (Fig. 2a and 2b).

The CLAAP preferentially cleaved alanine- $\beta$ naphthylamide followed by leucine- $\beta$-naphthylamide and glycine- $\beta$-naphthylamide (Table 2 ) in agreement with chicken intestine aminopeptidase (Jamadar et al., 2003), bovine skeletal muscle alanine aminopeptidase ( $\mathrm{Ye}$ and $\mathrm{Ng}, 2011$ ) and the two alanyl aminopeptidases of Trypanosoma congolense (Pillay et al., 2013). The CLAAP displayed its optimum activity at $\mathrm{pH} 8$ (Fig. 3 ). Various alanine aminopeptidases displayed the same optimum $\mathrm{pH}$; alanine aminopeptidase from bovine skeletal muscle (Ye and $\mathrm{Ng}$, 2011), the two alanyl aminopeptidases of Trypanosoma congolense (Pillay et al., 2013) and human pancreas alanine aminopeptidase (Sidorowicz et al., 1980). The CLAAP displayed $\mathrm{Km}$ value of $0.083 \mathrm{mM}$ alanine $\beta$-naphthylamide (Fig. 3). This value is closely related to $0.1 \mathrm{mM}$ that of chicken intestine aminopeptidase (Mane et al., 2010). The low Km value explains the CLAAP high affinity toward alanine $\beta$-naphthylamide. The CLAAP activity was increased in the presence of $\mathrm{CoCl}_{2}$ and $\mathrm{MgCl}_{2}$, while $\mathrm{CuCl}_{2}, \mathrm{MnCl}_{2}$ and $\mathrm{ZnCl}_{2}$ inhibited the CLAAP activity drastically (Table 3). Similar to CLAAP, the bovine skeletal muscle alanine aminopeptidase is inhibited by $\mathrm{Zn}^{2+}$ and $\mathrm{Mn}^{2+}$ and in contrast with it; it is strongly inhibited by $\mathrm{Co}^{2+}$ and $\mathrm{Mg}^{2+}$ ions (Ye and $\mathrm{Ng}, 2011$ ).

In this study, the effect of various inhibitors on the purified camel liver AAP revealed that, CLAAP was resistant to DTT, N-Ethylmalimide, $\beta$-Mercaptoethanol and TPCK. It was inhibited with bestatin, glutathione, 1,10 phenanthroline, PMSF, puromycin, soya bean trypsin inhibitor and TLCK. The purified CLAAP is suggested to have a cysteine protease activity due to its sensitivity to the cysteinyl protease inhibitor $p$ chloromercuribenzoic acid. It also suggested having a serine protease activity due to the sensitivity to PMSF and soya bean trypsin inhibitor suggesting the presence of serine residue in the enzyme active site. The CLAAP inhibition with 1,10 phenanthroline indicates that CLAAP is a metalloenzyme in similarity with porcine liver (Imamura et al., 1983) and rabbit kidney aminopeptidases (Oliveira et al., 1999). Bestatin is reported as a specific inhibitor of alanyl aminopeptidases (Tieku and Hooper, 1992). Here, bestatin inhibited CLAAP vigorously since $100 \mu \mathrm{M}$ bestatin inhibited the enzyme completely (Table 4) confirming that it is an alanine aminopeptidase. A straight line was obtained when drawing the Hill plot for the bestatin inhibition of the purified CLAAP. The Hill plot has a slope of 1.11 indicating that there is one binding site for bestatin on CLAAP molecule
(Fig. 4b). Bestatin inhibited CLAAP competitively since the bestatin existence did not alter the Vmax value and increased the $\mathrm{Km}$ value (Fig. 4c). To determine the $\mathrm{K} i$ value, we plotted slopes of the reciprocal plots lines against the bestatin concentrations. The CLAAP bestatin inhibition Ki value was found to be $14 \mu \mathrm{M}$ directly from the plot $\mathrm{X}$ axis intercept (Fig. 4d). The low $\mathrm{K} i$ value proves that the bestatin is a potent inhibitor of alanine aminopeptidases. In conclusion, this report presents a simple, convenient and reproducible method for purification of alanine aminopeptidase from the camel liver as a safe, locally available and rich source. Large scale production of this well characterized enzyme will allow its using in different applications as in meat and dairy products industry in removing pitter peptides and in examination of the protein primary structure.

\section{ACKNOWLEDGEMENTS}

Financial support and sponsorship: The authors would gratefully acknowledge financial support and fund provided by the National Research Centre, Egypt under the contract No. P101101.

Conflict of Interests: There are no conflicts of interest.

\section{REFERENCES}

Barrett AJ., Rawlings ND., Woessner JF. 1998. Handbook of Proteolytic Enzymes. Academic Press, New York.

Bogra P., Singh J., Singh H. Purification and characterization of aminopeptidase B from goat brain. Proc. Biochem. 2009; 44: 776-780.

Bradford MM. A rapid and sensitive method for the quantitation of microgram quantities of protein utilizing the principle of protein-dye binding. Anal. Biochem 1976; 72: 248-254.

Brownless J., Williams $\mathrm{CH}$. Peptidases, peptides and the mammalian blood-brain barrier. J. Neurochem. 1993; 60: 780-793.

Chien HCR., Lin LL., Chao SH., Chen CC., Wang WC., Shaw CY., Tsai YC., Hu HY., Hsu WH. Purification, characterization, and genetic analysis of a leucine aminopeptidase from Aspergillus sojae. Biochim. Biophys. Act. 2002; 1576: 119-126.

Drag M., Grembecka J., Pawełczak M., Kafarski P. $\alpha$ Aminoalkylphosphonates as a tool in experimental optimization of P1 side chain shape of potential inhibitors in S1 pocket of leucine and neutral aminopeptidases. Eur. J. Med. Chem. 2005; 40: 764-771.

Erbeznik H., Hersh LB. A novel mammalian high-molecular weight aminopeptidase. Arch. Biochem. Biophys. 1997; 344: 228-234.

Fernandez-Espla MD., Rul F. Peptidase from Streptococcus thermophilus. A new member of the aminopeptidase $\mathrm{T}$ family of thermophilic bacteria. Eur. J. Biochem. 1999; 263: 502 - 510.

Flynn FV. Assessment of renal function: selected developments. Clin. Biochem. 1990; 23: 49-54.

Hiroi Y., Endo Y., Natori Y. Purification and properties of an aminopeptidase from rat-liver cytosol. Arch. Biochem. Biophys. 1992; 294: 440-445.

Huang K., Takahara S., Kinouchi T., Takeyama M., Ishida T., Ueyama H., Nishi K., Ohkubo I. Alanyl amino- peptidase from human seminal plasma: purification, characterization and immunohistochemical localization in the male genital tract. J. Biochem. 1997; 122: 779-787.

Imamura T., Kawata S., Ninomiya K., Makisumi S. Porcine liver aminopeptidase. Further characterization of its sulfhydryl groups. J. Biochem. 1983; 94: 267-273.

Itoh C., Nagamatsu A. An aminopeptidase activity from porcine kidney that hydrolyzes oxytocin and vasopressin: Purification and partial characterization. Biochim. Biophys. Act. 1995; 1243: 203-208. 
Jamadar VK., Jamadar SN., Dandekar SP., Harikumar P. Purification and characterization of aminopeptidase from chicken intestine. J. Food Sci. 2003; 68: 438-443.

Kawata S., Takayama S., Ninomiya K., Makisumi S. Purification and some properties of porcine liver aminopeptidase B. J. Biochem. 1980; 88: 1025-1032.

Laemmli UK. Cleavage of structural proteins during the assembly of the head of Bacteriophage T4. Nature 1970; 227: 680-685.

Magboul AAA., McSweeney PLH. Purifiation and characterization of an aminopeptidase from Lactobacillus curvatus DPC2024. Int. Dairy J. 1999; 9: 107-116.

Mane S., Damle M., Harikumar P., Jamdar S., Gade W. Purification and characterization of aminopeptidase $\mathrm{N}$ from chicken intestine with potential application in debittering Process. Biochemistry 2010; 45: 1011-1016.

Mantle D., Hardy MF., Lauffart B., Mcdermott JR., Smith AI., Pennington RJT. Purification and characterization of the major aminopeptidase from human skeletal muscle. Biochem. J. 1983; 211: 567573.

Mantle D., Lauffart B., Mcdermott J., Gibson A. Characterization of aminopeptidases in human kidney soluble fraction. Clin. Chim. Acta 1990; 187: 105-113.

Martinez-Cuesta MC., Fernandez de Palencia P., Requena T., Pelaez C. Enzymatic ability of Lactobacillus casei subsp. casei IFPL731 for flavour development in cheese. Internl. Dairy J. 2001; 11: 577-585.

Matsui M., Fowler JH., Walling LL. Leucine aminopeptidases: diversity in structure and function. Biol. Chem. 2006; 387: 1535-1544.

Mizutani S., Goto K., Nomura S. Possible action of human placental aminopeptidase $\mathrm{N}$ in feto-placental unit. Res. Commun. Chem. Pathol. Pharmacol. 1993; 82: 65-80.

Niven GW. The characterization of two aminopeptidase activities from the cyanobacterium Anabaena flosaquae. Biochim. Biophys. Acta 1995; 1253: 193-198.

Offner GD., Gong D., and Afdhal NH. Identification of a 130kilodalton human biliary concanavalin $\mathrm{A}$ binding protein as aminopeptidase N. Gastroenterology. 1994; 106: 755-762.

Oliveira SM., Freitas Jr J.O., Alves KB. Rabbit kidney aminopeptidases: purification and some properties. Immunopharmacol. 1999; 45: 215-221.
Pillay D., Boulangé AV., Coustou V., Baltz T., Coetzer THT. Recombinant expression and biochemical characterization of two alanyl aminopeptidases of Trypanosoma congolense. Exp. Parasit. 2013, 135: 675-684

Renwrantz L., Lam A. Soluble and surface-bound aminopeptidase in eosinophilic blood cells from Mytilus edulis. J. Invert. Pathol. 2010; 103: 68-70.

Sidorowicz W., Iackson GC., Behal FJ. Multiple molecular forms of human pancreas alanine aminopeptidase. Clin. Chim. Acta 1980; 104: $169-179$.

Smith I. Acrylamide gel disc electrophoresis. In: Smith, I., (Eds.), Electrophoretic techniques, Academic press, New York, 1969; pp. 365-515.

Tieku S., Hooper NM. Inhibition of aminopeptidases N, A and W. A re-evaluation of the actions of bestatin and inhibitors of angiotensin converting enzyme. Biochem. Pharmacol. 1992; 44: 1725-1730.

Umetsu H., Arai M., Ota T., Kudo R., Sugiura H., Ishiyama H., Sasak K. Purification and properties of an aminopeptidase from the midgut gland of scallop (Patinopecten yessoensis). Comp. Biochem. Physiol. 2003; 136: 935-942.

Weber K, Osborn M. The reliability of molecular weight determinations by dodecyl sulfate-polyacrylamide gel electroph. J. Biol Chem. 1969; 244: 4406-4412.

Yamamoto Y., Li YH., Ushiyama I., Nishimura A., Ohkubo I., Nishi K. Puromycin-sensitive alanyl aminopeptidase from human liver cytosol: purification and characterization. Forensic Sci. Int. 2000; 113: 143-146.

Ye XJ., Ng TB. Purification and characterisation of an alanine aminopeptidase from bovine skeletal muscle. Food Chemistry 2001; 124: 634-639.

\section{How to cite this article:}

Masoud HM, Darwish DA, Helmy MS, Abdel-Monsef MM. Purification and properties of an alanine aminopeptidase from camel liver. J App Pharm Sci, 2017; 7 (05): 123-128. 